\title{
問題の階層構造を利用した経路最適設計の一手法*
}

\author{
花原 和之*1, 多田 幸生 ${ }^{* 1}$
}

\section{An Optimal Path Design Taking Advantage of Hierarchical Structure of Problem}

\author{
Kazuyuki HANAHARA ${ }^{* 1}$ and Yukio TADA \\ ${ }^{* 1}$ Department of Systems Science, Graduate School of System Informatics, Kobe University \\ 1-1, Rokkodai, Nada, Kobe, Hyogo, 657-8501, Japan
}

\begin{abstract}
Optimal path design is a problem that is considered to have wide range of applications. In this study, we deal with a path design problem of a pattern that consists of a number of small pattern elements; a pattern consisting of characters or symbols is a typical example. In such a case, we can naturally introduce a kind of hierarchical structure to the problem. We develop an approach to this type of path design problem that takes advantage of the hierarchical structure. In order to avoid the degradation of the optimality of the solution due to the separation of the problem by means of the introduction of hierarchical layers, we utilize an abstraction of the paths of the small pattern elements that make up the entire pattern. A local optimization approach in order to reduce the computational cost is also proposed. Path design problems of patterns consisting of alphabet character patterns are dealt with as examples; the applicability and the performance of the proposed optimal path design approach are discussed.
\end{abstract}

Key Words : Path Design, Hierarchical Structure, Optimization, Traveling Salesman Problem

\section{1. 緒言}

巡回セールスマン問題 ${ }^{(1)} に$ 代表される経路最適設計問題は典型的な組合せ最適化問題として知られている. この ような問題が実用的な規模を持つ場合, 弚の厳密解を現実的な処理時間で求めることは一般に困難であり, K-opt 法 ${ }^{(2)}$ に代表される近似的手法や遺伝的アルゴリズム, 焼きなまし法 (シミュレーテッド・アニーリング) といったヒュー

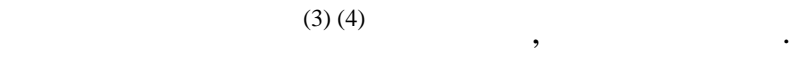

本研究では, 対象とする経路設計問題を階層的な観点から取り扱う. 巡回セールスマン問題を階層的に取扱った 例としては内田らの研究 ${ }^{(5)}$ や Graham らの研究 ${ }^{(6)}$ がある. これらは一般的な問題に対し, 基本的には上層的あるいは 全体的な階層から下層的あるいは局所的な階層へ, 言わばトップダウン的に問題を取り扱うものである. これに対 し, 本研究では問題乥れ自身が階層構造を保有する場合あるいは問題に自然な形で階層構造が導入可能な場合を取 り扱い, 基本的には局所的な部分構造である下層的な階層から弚れらの集合体として構成される全体的な階層へ, ボトムアップ的な観点から問題を取り扱う.

大規模な設計問題や最適化問題を階層的な観点から取り扱う研究はこれまでにもいくつかなされており,ボトム アップ的に階層構造を導入した例もいくつか報告されている. 例えば, Haxhimusa らの研究 ${ }^{(7)}$ では, 巡回セールスマ ン問題において幾何学的な位置関係の観点からボトムアップ的に多層的な階層構造を構築するアプローチが示さ

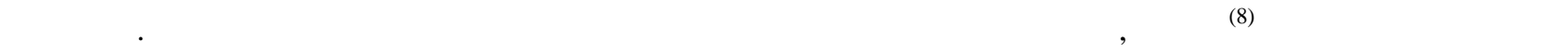

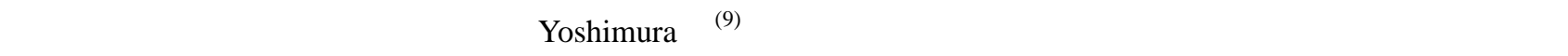

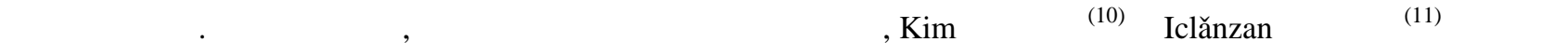
ように, 構築された階層構造にもとづく上位階層と下位階層の間の相互作用を通じ, コンカレント的に最適解の探

* 原稿受付 2012 年 4 月 6 日

${ }^{* 1}$ 正員, 神戸大学大学院システム情報学研究科システム科学専攻

（广657-8501 兵庫県神戸市灘区六甲台町 1-1）

E-mail: hanahara@cs.kobe-u.ac.jp 
索が行われている.

本論文では, 問題が明示的な形で階層的な部分構造を持つ経路設計問題における, 部分構造に対する経路の抽象化 による全体問題の効率的な解法を提案する. 階層構造の構築は, 部分から全体へとボトムアップ的に行われるが, 光 の際に個々の部分構造に対する解経路の探索を行い,複数の解経路候補によって部分構造を抽象化する. 全体構造 の最適化においては弚れらの抽象化された部分構造を用いて解の探索を行うため, 提案手法においては解の探索過 程もボトムアップ的なものとなる. また,このような抽象化の観点から問題の階層構造を利用することにより, 種々 の規模の部分構造に対する解経路をデータベース化し再利用することも容易となる.

具体的には, 本論文では複数の文字パターンによって構成される図形の描画の際の総移動距離の最小化を扱う. 個々の文字パターンに対する経路設計問題を部分問題とし, 弚れらを解経路によって抽象化することによる全体問 題の定式化を示す. このような定式化を用いた場合でも, 経路設計問題が本質的には組み合わせ最適化問題である ことに変わりはなく,ある程度大きな規模の問題への適用は実際的ではない. 乥こで,計算量のさらなる低減のため, ある種の局所最適化の考え方を導入した問題の解法を提案する.

いくつかの計算例を示し, 本論文で提案する部分問題の抽象化による定式化および局所最適化による解法の有効 性について検討する.

\section{2. 経路設計問題における階層構造}

縦軸ならびに横軸に配置された駆動装置によりペンを移動させて二次元図形を描画するX-Y プロッタや, 二軸の ミラーによりレーザをスキャンすることにより図形を描画する機器を考える. これらの機器によって描画される図 形が文字や記号のパターンの集合である場合, 経路設計問題は, 文字パターン間の移動経路の設計と文字パターン 乥れ自身の描画経路の設計という, 二つの階層により構成されていると考えることができる.

また, 巡回セールスマン問題は空間 (一般には平面) に配置された全ての点 (都市) を通過する最短経路を求める 問題であるが, これらの点の集合を何らかの形で複数のブロックに分割することができる場合, この問題をブロッ ク間の移動経路の設計とブロック内の移動経路の設計という, 二つの階層により構成されているととらえることが できる.

本論文では主として前者の場合について考察するが, 何らかの形で階層構造の導入が行われれば, 問題の取扱い の上で両者に本質的な差異はない.ただし,このような階層構造を用いて問題を分割して扱う場合, 乥の結果の最適 解として得られる経路が, 導入される階層構造, 特に下位構造のブロック分割の構成によって大きく影響を受ける 可能性があることに注意が必要である.

なお, 本論文では図形描画の際の単純な総移動距離の最小化のみを取り扱っている. しかしながら,状況によって は,プロッタによる文字の描画経路における筆順最適化を取り扱った田口の研究 ${ }^{(12)} に$ 見られるように, ペンの上げ 下げの影響といった種々の他の要因をも含めて経路設計を行う必要がある場合も考えられる. 提案手法では, 下位 構造である個々の文字パターンを关の複数の描画経路候補によって抽象化して取り扱う.すなわち, このような場 合においてもペンの上げ下げ等が経路設計に及ぼす影響を文字単位あるいは部分構造単位の抽象化過程にのみ限 定することにより, 基本的には全く同樣に問題を取り扱うことができる.

\section{3. 目的関数である経路長の定式化}

本論文では, 経路設計問題が二つの階層からなる場合を取り扱う.すなわち, 個々の文字パターンの描画のための 経路 (下位構造) と乥れらの文字パターン間の移動のための経路 (上位構造) である.

\section{$3 \cdot 1$ 文字パターンの描画経路長}

文字パターン $c$ が $N_{c}$ 本の線 $1, \cdots, N_{c}$ で構成されている場合を考える. 文字パターン $c$ の線 $i$ の長さを $l_{c i}$, 弚の両 端点の位置を $x_{c i(0)}$ および $x_{c i(1)}$ と表わす. なお, 両端点の位置は文字パターンに固定された座標系を参照するもの としている. 本研究では, 文字パターンを構成する個々の線の長さと端点の位置のみが問題となるため, 線は必ずし も直線である必要はない. 図 1 に 3 本の線で構成される文字 'A' の場合を示す $\left(N_{\mathrm{A}^{\mathrm{A}}}=3\right)$. 実際のこれらの線の描画 


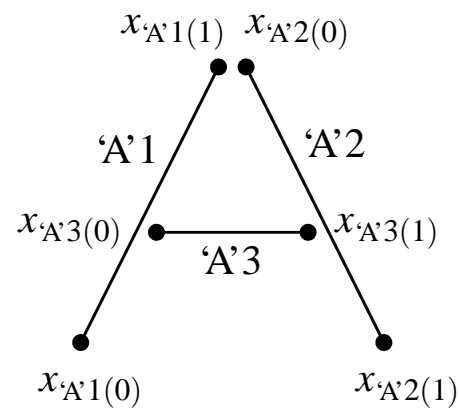

Fig. 1 Character 'A' consisting of three lines, 'A'1, 'A'2 and 'A'3

順序や向きは経路設計によって定められる. したがって, 文字を構成する個々の線や乥の端点に付された番号はあ くまで識別のみのためのものに過ぎない.

この場合, 文字パターン $c$ に対する描画経路は, $1, \cdots, N_{c}$ の置換によって表わされる線の描画順序 $\alpha_{c 1}, \cdots, \alpha_{c N_{c}}$ お よび個々の線の描画の向きを 0 か 1 の二值で表わす $\beta_{c 1}, \cdots, \beta_{c N_{c}}$ によって定まる. これにより, 文字パターン $c$ の 描画経路長 $L_{c}$ が以下のように表わされる.

$$
L_{c}=\sum_{i=1}^{N_{c}} l_{c i}+\sum_{i=1}^{N_{c}-1} d_{c i}
$$

ここで, $d_{c i}$ は文字パターン $c$ の描画において $i$ 番目に描画される線 $\alpha_{c i}$ の終点位置から $i+1$ 番目に描画される線 $\alpha_{c(i+1)}$ の始点位置までの移動距離であり,

$$
d_{c i}=d_{c i}\left(\alpha_{c i}, \beta_{c i}, \alpha_{c(i+1)}, \beta_{c(i+1)}\right)=\left\|x_{c \alpha_{c(i+1)}\left(\beta_{c(i+1)}\right)}-x_{c \alpha_{c i}\left(1-\beta_{c i}\right)}\right\|
$$

である. ここで $\|\cdot\|$ はユークリッドノルムを表す. なお, $i$ 番目に描画する線 $\alpha_{c i}$ の描画方向は, $\beta_{c i}=0$ のとき始点 が $x_{c \alpha_{c i}(0)}$ で終点 $x_{c \alpha_{c i}(1)}$ であるとし, $\beta_{c i}=1$ のとき始点 $x_{c \alpha_{c i}(1)}$, 終点 $x_{c \alpha_{c i}(0)}$ としている. 文字パターン $c$ 全体の描 画経路の始点 $x_{c(0)}$ および終点 $x_{c(1)}$ は, 最初 (1 番目) に描画する線の始点と最後 $\left(N_{c}\right.$ 番目) に描画する線の終点であ るから,

$$
x_{c(0)}=x_{c \alpha_{c 1}\left(\beta_{c 1}\right)}, \quad x_{c(1)}=x_{c \alpha_{c N_{c}}\left(1-\beta_{c N_{c}}\right)}
$$

となる

文字パターン $c$ の描画経路の設計変数として

$$
\mathrm{T}_{c}=\left[\alpha_{c 1}, \beta_{c 1}, \cdots, \alpha_{c N_{c}}, \beta_{c N_{c}}\right]
$$

を導入すれば,式 (1)-(3) は以下の一般的な形式にまとめられる.

$$
\begin{aligned}
L_{c} & =L_{c}\left(\mathrm{~T}_{c}\right) \\
x_{c(j)} & =x_{c(j)}\left(\mathrm{T}_{c}\right) \quad(j=0,1)
\end{aligned}
$$




\section{$3 \cdot 2$ 文字パターンによって構成される全体パターンの描画経路長}

文字パターン $c_{n}$ を位置 $p_{n}$ に縮尺 $s_{n}$ および回転角 $\theta_{n}$ で $N$ 個 $(n=1, \cdots, N)$ 配置した全体パターンを描画する場 合を考える.ただし, $p_{n}$ は文字パターン $c_{n}$ の座標系の原点の配置位置を表す. 個々の文字パターンに対する描画経 路が全て定まっていれば, この場合の全体パターンの描画経路は $1, \cdots, N$ 置換によって表わされる文字パターン の描画順序 $\alpha_{1}, \cdots, \alpha_{N}$ によって定まり, 弚の場合の全描画経路長 $L$ は

$$
L=\sum_{n=1}^{N} s_{n} L_{c_{n}}+\sum_{n=1}^{N-1} d_{n}
$$

である. ここで, $d_{n}$ は $n$ 番目に描画する文字パターンの終点から $n+1$ 番目に描画する文字パターンの始点までの 移動距離であり,

$$
d_{n}=\left\|\left(s_{\alpha_{n+1}} R\left(\theta_{\alpha_{n+1}}\right) x_{c_{\alpha_{n+1}}(0)}+p_{\alpha_{n+1}}\right)-\left(s_{\alpha_{n}} R\left(\theta_{\alpha_{n}}\right) x_{c_{\alpha_{n}}(1)}+p_{\alpha_{n}}\right)\right\|
$$

である.ただし, $R(\theta)$ は回転角 $\theta$ に対応する回転行列である.

\section{4. 階層構造を用いた経路長最小化問題の定式化}

本研究で扱う最適設計問題における目的関数は,式(7)および(8)によって表わされる全描画経路長 $L$ である. 光 の最小化に関連し, 基本となる考え方である下位構造と上位構造を完全に分離した最適設計問題の定式化について 述べ, さらに, 本研究で提案する個々の文字パターンの描画経路の抽象化にもとづく定式化について述べる.

\section{$4 \cdot 1$ 階層を分離した定式化}

本研究の目的関数である式 (7) は, 文字パターン毎の経路長 $L_{c_{n}}$ と光れらの間の移動距離 $d_{n}$ の線形結合によって 表わされることから, 二つの階層の最適化問題を独立のものとして定式化することができる.すなおち, 式 (1) で表 わされる個々の文字パターン $c$ についての経路長最小化問題

と, この解 $\mathrm{T}_{c}$ と光れによって定まる $L_{c}, x_{c(0)}, x_{c(1)}$ にもとづいて式 (7) により定まる全経路長 $L$ の最小化問題

$$
\text { Minimize } L \text { with respect to } \alpha_{1}, \cdots, \alpha_{N}
$$

\section{を独立のものとして扱うものである}

この場合, 全ての文字パターン $c$ に対し問題 (9) の解を予め求めることにより, 最適経路設計問題 (10) は文字パ ターンの描画順序 $\alpha_{1}, \cdots, \alpha_{N}$ のみの問題に帰着される.

\section{2 文字パターン毎の描画経路の抽象化にもとづく定式化}

前節で述べた定式化は単純であり,これにもとづいて得られる解にもある程度の最適性は期待できる. しかしな がら, 個々の文字パターンの描画経路最適化と文字パターンの描画順序の最適化か完全に分離されているため, 图 2 に示すような文字パターン間の移動が不合理に長大となる解が得られてしまう可能性がある. 図 2 においては始点 および終点が・および○, 描画を伴う移動が黑の実線, 描画を伴わない移動が赤の破線で示されているが, 'O’から ‘B’および ‘B’から ‘E’ の移動の際の長い移動の赤の破線が確認できる. これを解消するためには, 上位構造の設計 


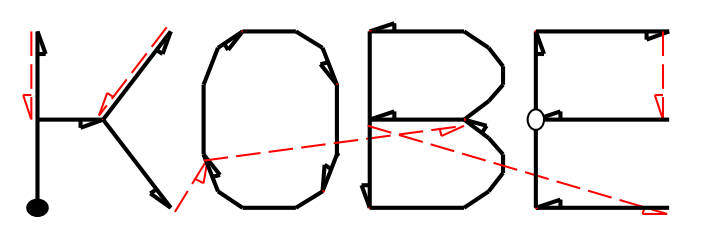

$(\bullet / \circ$ : initial/final points, $\square:$ drawing direction, $\longrightarrow \smile:$ moving direction)

Fig. 2 Example inappropriate path obtained based on separated simple hierarchical formulation: see the long traveling distances between ' $\mathrm{O}$ ' to ' $\mathrm{B}$ ' and ' $\mathrm{B}$ ' to ' $\mathrm{E}$ '

変数である文字パターンの描画順序 $\alpha_{1}, \cdots, \alpha_{N}$ と下位構造の設計変数である各文字パターンの描画経路 $\mathrm{T}_{c_{1}}, \cdots \mathrm{T}_{c_{N}}$ の双方を同時に考慮し, 最適化問題を以下のように定式化すればよい.

$$
\text { Minimize } L \text { with respect to } \alpha_{1}, \cdots, \alpha_{N}, \mathrm{~T}_{c_{1}}, \cdots, \mathrm{T}_{c_{N}}
$$

しかしながら, 経路最適化問題は本質的に組み合わせ最適化問題であるため, 置換を表す設計变数 $\alpha_{1}, \cdots, \alpha_{N} に$ 式 (4) で表わされる $\mathrm{T}_{c_{n}}(n=1, \cdots, N)$ を谷のまま加えたこのような定式化では, $\mathrm{T}_{c_{n}}$ に含まれる組み合わせの影響もあ り,たとえ文字パターンの数が少ない場合でも問題の規模が各段に大きくなってしまう.

そこで本研究では, 個々の文字パターン $c$ について产の単体での描画経路のうち, 上位 $P$ 個の最適解を問題 (9) を 解くことによって予め準備し, 1 から $P$ の值をとるパラメータ $\gamma$ とって

$$
\mathrm{T}_{c}=\mathrm{T}_{c}(\gamma)
$$

と抽象化する.ただし，

$$
L_{c}\left(\mathrm{~T}_{c}(1)\right) \leq L_{c}\left(\mathrm{~T}_{c}(2)\right) \cdots \leq L_{c}\left(\mathrm{~T}_{c}(P)\right)
$$

である. すなわち, 各文字パターンの描画経路の可能性を $P$ 個に限定する. これにより, 次の形の最適経路設計問題 を得る.

$$
\text { Minimize } L \text { with respect to } \alpha_{1}, \cdots, \alpha_{N}, \gamma_{1}, \cdots, \gamma_{N}
$$

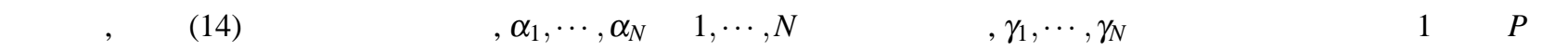
值を取り得る, 異なる性質を持つことに注意が必要である.

\section{5. 解 法 の 検 討}

各文字パターンの描画経路を抽象化した問題 (14) は元々の問題 (11) に比べれば実質的な設計变数の数をかなり 抑制できているが, 本質的には組み合わせ最適化問題である. ここでは, 計算量を低減するためのデータベース化と 局所最適化手法の導入について述べる. 
5.1 文字パターンの描画経路の抽象化の実際とデータベース化

前節で個々の文字パターンに対する描画経路の抽象化を導入した. 文字パターン $c$ に対する $P$ 個の経路は, 基本 的には全ての可能な経路の中から経路長が短い順に採用し, 式 (12)および(13)のようにパラメータ化を行う. し かしながら, 全体パターンの経路設計における最適性の観点から文字パターン間の可能な移動経路の選択肢につい て考えれば, 抽象化して得られた文字パターンの $P$ 個の描画経路の両端点位置は多樣であることか望ましい. した がって, 前節で述べた抽象化処理においては, 両端点位置か類似している描画経路, すなわち文字パターン $c$ の大き さ $D_{c}$ に対し,

$$
\left\|x_{c(0)}\left(\mathrm{T}_{c}\right)-x_{c(0)}\left(\mathrm{T}_{c}^{\prime}\right)\right\| \leq r D_{c} \quad \text { and } \quad\left\|x_{c(1)}\left(\mathrm{T}_{c}\right)-x_{c(1)}\left(\mathrm{T}_{c}^{\prime}\right)\right\| \leq r D_{c}
$$

を満たす $\mathrm{T}_{c}$ と $\mathrm{T}_{c}^{\prime}$ については経路長の短いもののみを採用することとし, $P$ 個に限定した描画経路の種類における 多樣性を確保する. ここで, $r$ は二つの経路の両端点の類似性を判定するための係数である. なお, 本研究では文字 パターン $c$ の大きさ $D_{c}$ として, 光の描画領域を囲む; 文字パターン $c$ の座標系を参照した最小矩形領域の対角線の 長さを用いている.

各文字パターンの経路最適設計問題を個別に解くことによるこのような抽象化処理は, 弚れらの文字パターンに よって構成される全体パターンの経路設計問題とは独立に実施することができる. また, 兴の結果は, 同一の文字パ ターンによって構成される樣々な経路設計問題に適用可能であることから,いったん得られた抽象化結果をデータ ベース化しておくことにより,効率的な問題の解法が可能となる.

\section{2 全ての組み合わせを評価する解法}

下位部分構造である各文字パターンの描画経路の抽象化を用いた経路設計問題 (14)の最も直接的な解法は, 兴の 全ての組み合わせを評価するものである. すなわち, 全体パターンを構成する文字パターンの描画順序を表す置換 $\alpha_{1}, \cdots, \alpha_{N}$ の $N$ ! 個の全ての組み合わせに対し, 個々の抽象化された文字パターンの描画経路パラメータ $\gamma_{1}, \cdots, \gamma_{N}$ の $P^{N}$ 個の全ての組み合わせを評価し, 全体経路が最短となるものを解とするものである. 抽象化した結果のデータ ベースを予め準備して利用する場合であれば, 個々の文字パターンの経路に関する処理はこの段階では不要となる. これは, 問題 (14) の意味での厳密解を探索することになるが, 評価する描画経路の組み合わせの数は $N ! P^{N}$ となる.

\section{$5 \cdot 3$ 各文字パターンの描画経路について局所最適化を利用する解法}

前節で述べた単純な解法では, $N$ ! 個の描画順序の置換の各々に対し, $P^{N}$ 個の組み合わせを評価する必要があり, 文字パターンの描画経路の抽象化処理を行った場合であっても比較的小規模の問題にしか適用できない. 弚こで, 本研究ではこの部分の計算量の低減のための次のような解法を提案する.

文字の描画順序を表す置換 $\alpha_{1}, \cdots, \alpha_{N}$ の $N$ ! 個の組み合わせの全てを評価する. ただし, 各文字パターンの描画経 路パラメータ $\gamma_{1}, \cdots, \gamma_{N}$ については以下の局所最適化を用いる:

\section{文字パターンの描画経路の局所最適化}

(1) 初期設定 パラメータを $\gamma_{1}=\gamma_{2}=\cdots=\gamma_{N}=1$ とし,個々の文字パターン単体での最短経路を設定する.

(2) 局所最適化 描画する文字パターンの順に局所的な最適化処理を行う. すなわち, $n$ を 1 から順に $N$ まて変化 させ, 兴の各々について全体経路長 $L$ を最小とする $\gamma_{\alpha_{n}}$ を他の $\gamma_{\alpha_{i}}(i=1, \cdots, N, i \neq n)$ が固定であるという条件 の下で求める.

(3) 繰り 返し 全体経路長 $L$ に改善が見られなくなるまで(2)の局所最適化を繰り返す.

この場合, (3) の繰り返し回数を $k$ 回とすれば, 評価する全体パターンの描画経路の組み合わせの数は $N ! k P N$ とな る. 実際には $k$ は 2,3 回から数回程度のことがほとんどであり, 前節の単純な解法の場合に比へて計算量を大きく 低減することができる. 


\section{4 計算量について}

この章で検討した解法に必要な計算量が実際にどの程度となるかについて以下の例題によって具体的に考察する.

• 文字の種類数を $M=40$ とし,簡単のため全ての文字が $N_{c}=4$ 本の線で構成されているとする.

- 各文字パターンの抽象化の際の描画経路の種類数は $P=6$ とする.

・経路設計の対象として, (1) $N_{1}=4$ 文字と (2) $N_{2}=8$ 文字の二つの場合を想定する.

この場合, 5.1 節で述べた描画経路の抽象化によるデータベース化を全ての文字パターンに対して行うために必 要な計算量は

$$
C_{D}=M N_{c} ! 2^{N_{c}} e=40 \times 4 ! \times 2^{4} e=1.5 \times 10^{4} e
$$

となる.ここで, $e$ は 1 回の描画経路長の評価に必要な計算量を表す.一度計算された経路長は抽象化処理の過程で 保持することができるため, この計算量は基本的に $P$ には影響されない.

このような抽象化にもとづき, $5 \cdot 2$ 節で述べた全ての組合せを評価して経路設計を行う場合の計算量は, 設計対象 (1)および (2)に対して

$$
C_{F}^{(1)}=N_{1} ! P^{N_{1}} e=4 ! \times 6^{4} e=3.1 \times 10^{4} e, \quad C_{F}^{(2)}=N_{2} ! P^{N_{2}} e=8 ! \times 6^{8} e=6.7 \times 10^{10} e
$$

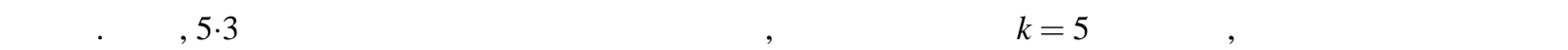

$$
C_{L}^{(1)}=N_{1} ! k P N_{1} e=4 ! \times 5 \times 6 \times 4 e=2.9 \times 10^{3} e, \quad C_{L}^{(2)}=N_{2} ! k P N_{2} e=8 ! \times 5 \times 6 \times 8 e=9.7 \times 10^{6} e
$$

となる.なお, 個々の文字パターンの抽象化処理を行うことなく,対象描画图形を構成する文字の個々の線について 全ての描画順序を評価して厳密解を探索する場合であれば, 兴の計算量は光れ光れ

$$
C_{A}^{(1)}=\left(N_{1} N_{c}\right) ! 2^{N_{1} N_{c}} e=(4 \times 4) ! \times 2^{4 \times 4} e=1.4 \times 10^{18} e, \quad C_{A}^{(2)}=\left(N_{2} N_{c}\right) ! 2^{N_{2} N_{c}} e=(8 \times 4) ! \times 2^{8 \times 4} e=1.1 \times 10^{45} e
$$

となる. 実際には, 文字によってパターンを構成する線の数は異なり, また 1 回の描画経路長の評価に必要な計算量 $e$ も線や文字の数の影響を受けるためこの計算量評価は概算であるが, 全体的な傾向を評価することはできる.

以上の計算例において $C_{A}$ と $C_{F}$ を比較すれば, データベース化に必要な計算量 $C_{D}$ を考慮した場合においても文 字パターンの抽象化によって経路最適設計に必要な計算量を大きく低減できることが確認できる. また, $C_{F}$ と $C_{L}$ の比較により,計算量軽減における局所最適化の効果も見ることができる. しかしながら, 以上の何れの場合におい ても,文字の描画順序の組合せ数の影響を受けるため, (1)の場合に比較して (2) の場合には計算量が非常に大きく なることも確認できる.

\section{6. 描画経路設計例}

階層構造を用いた経路最適設計問題の定式化と前節で導入した解法について,設計例にもとづき, 計算時間と設 計解の最適性の観点から検討を加える. なお, 参考のために示している計算時間は通常のデスクトップ型の PCに よって処理を行った場合のものである. 


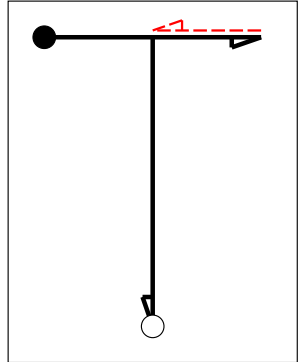

(a1) $\gamma=1(L=1.70)$

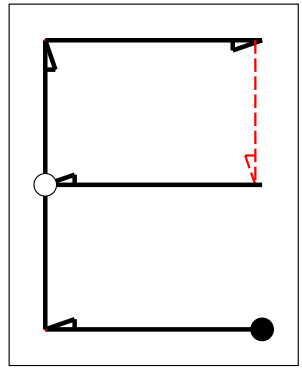

(b1) $\gamma=1(L=3.00)$

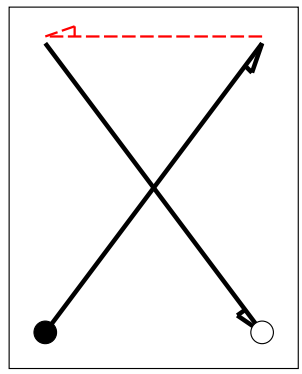

(c1) $\gamma=1(L=2.60)$

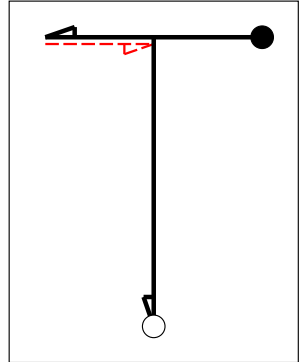

(a2) $\gamma=3(L=1.70)$

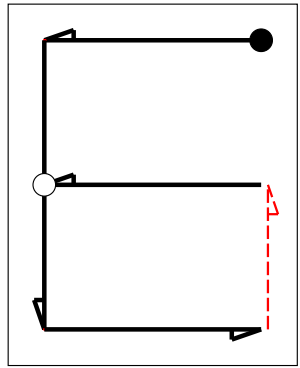

(b2) $\gamma=3(L=3.00)$

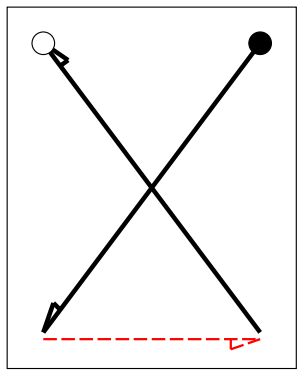

(c2) $\gamma=3(L=2.60)$

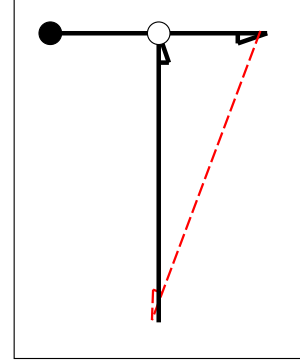

(a3) $\gamma=5(L=2.25)$

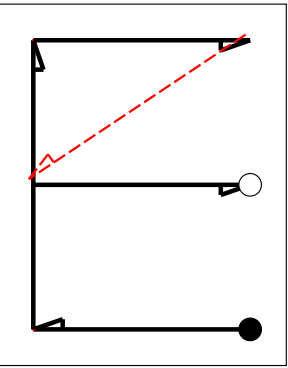

(b3) $\gamma=5(L=3.32)$

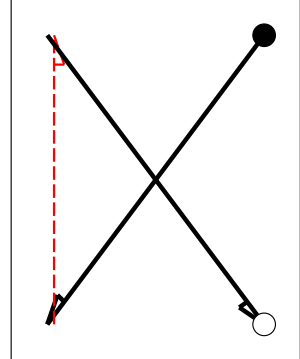

(c3) $\gamma=5(L=2.80)$

$(\bullet / \circ$ : initial/final points,

: drawing direction,

: moving direction)

Fig. 3 Example of drawing pattern abstraction for ' $\mathrm{T}$ ', ' $\mathrm{E}$ ' and ' $\mathrm{X}$ ' $(P=6, r=0.2)$

\section{1 文字パターンの描画経路の抽象化例}

図 3 に文字パターンの描画経路の抽象化の例を示す. 各文字パターンにおける可能な描画経路の数は $P=6$ とし,

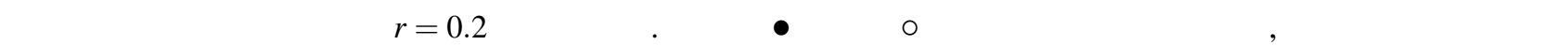
経路,すなわち○が始点で・が終点の場合 $(\gamma=2,4,6)$ は省略されている.

この抽象化処理は個々の問題が比較的小規模であるため, アルファベットと記号の 34 文字に対して実施した場 合で 6.2 秒程度の処理時間で行うことができた.

\section{$6 \cdot 2$ 階層構造導入の影響評価}

階層構造を用いず, 全体パターンを構成する文字パターンの全ての線を個別に扱い, 光れらの線の描画順序と描画 の向きの全ての組み合わせから厳密解を求めた例を図 4(a) に示す. 得られた最適描画経路は図に示すように各文字 パターン毎とはなっていない. この場合, 全体パターンを構成する線の本数は高々 10 本であるが, 弚の全ての描画経 路の組み合わせの数は $10 ! \times 2^{10}$ すなわち $3.7 \times 10^{9}$ 程度となり, この解を得るのに 3 千秒もの時間が必要であった.

問題 (9) を単純に解けば, 文字パターン ‘T’, ‘E’, ‘X’ に対して図 3(a1), (b1), (c1) に示す描画経路が得られる. これ らの結果を用い, 問題 (10) によって文字パターンの描画順序のみを最適化した場合の全体パターンの最適描画経路 を図 4(b1) に示す.これは, 文字パターンに関する処理と全体パターンに関する処理を完全に分離して行ったもの である. この例では得られた描画順序は単純に左から右となっている. この場合, 特に左の ‘ $\mathrm{T}$ ’ と 'E', ‘ $\mathrm{E}$ ’ と ‘ $\mathrm{X}$ ’の 


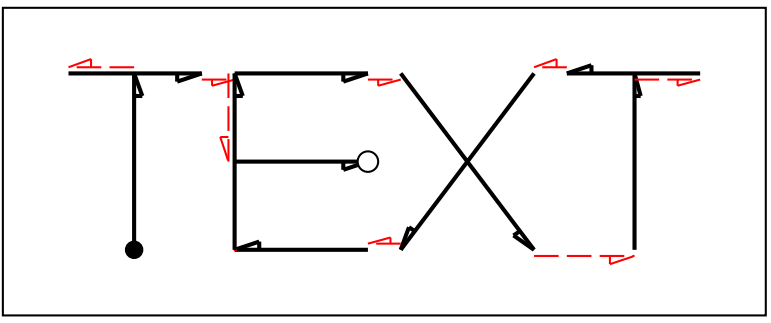

(a) Exact solution of the original problem

(CPU time: $2947 \mathrm{~s}, L=3.55$ )

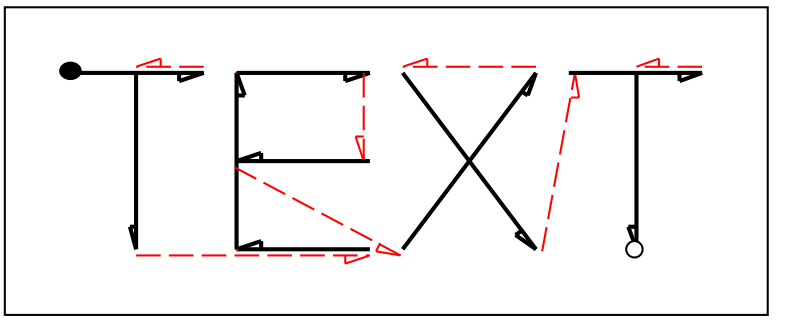

(b1) Simple optimal solution $(P=1)$

(CPU time: 0s, $L=4.39$ )

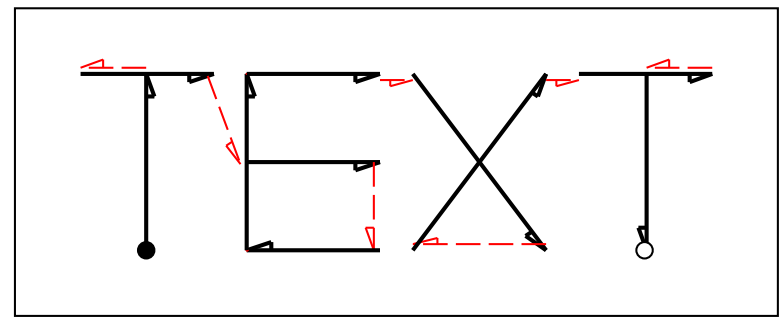

(b2) Using path abstraction $(P=6)$

(CPU time: $0.014 \mathrm{~s}, L=3.65$ )

(b) Solution based on hierarchical formulation

$(\bullet / \circ$ : initial/final points, $\square:$ drawing direction, $-\neg:$ moving direction)

Fig. 4 Example optimal design based on hierarchical formulation-1

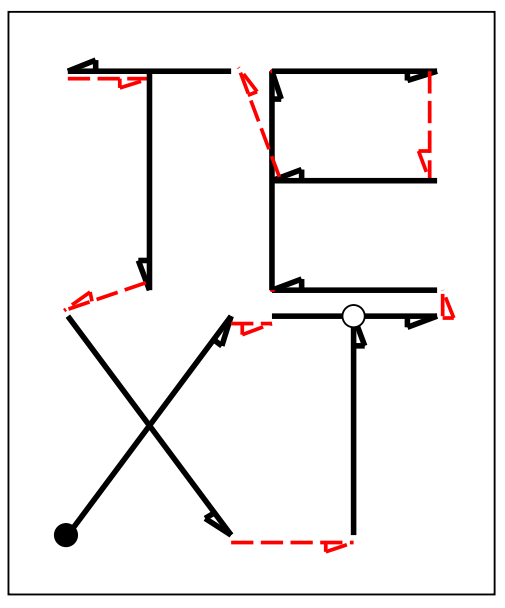

(a) Exact solution

(CPU time: $2957 \mathrm{~s}, L=3.58$ )

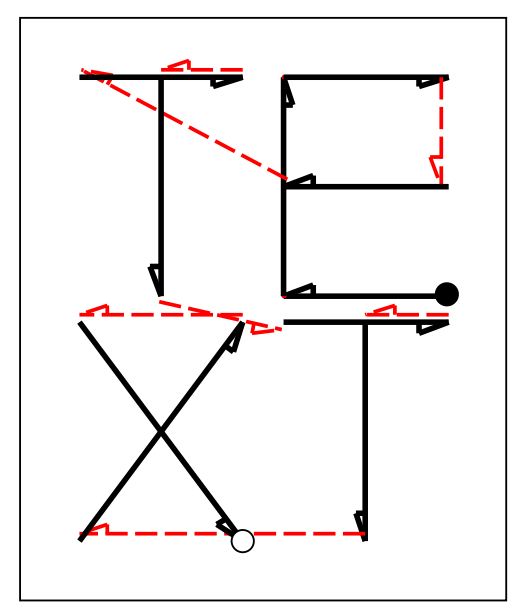

(b1) Simple solution $(P=1)$ (CPU time: 0 s, $L=4.26$ )

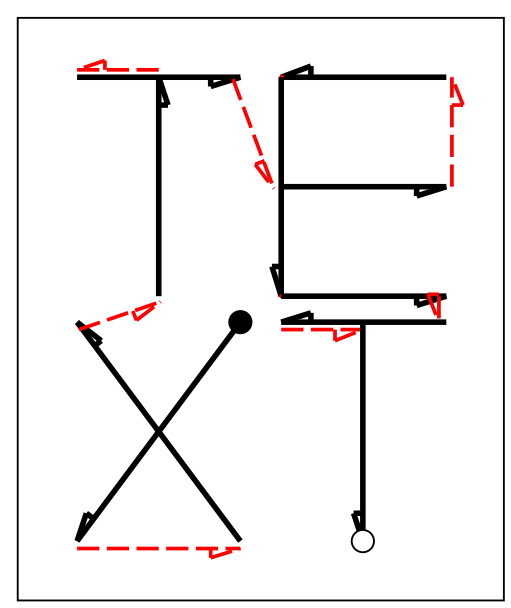

(b2) Path abstraction $(P=6)$

(CPU time: $0.012 \mathrm{~s}, L=3.69$ )

(b) Solution based on hierarchical formulation

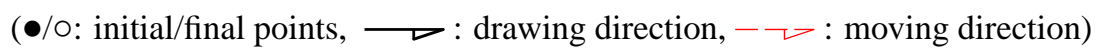

Fig. 5 Example optimal design based on hierarchical formulation-2

間で隣接する文字パターン間の移動距離が長大になっていることがわかる.

$6 \cdot 1$ 節で行った文字パターンの描画経路の抽象化の結果を用い, 問題 (14) の定式化と $5 \cdot 2$ 節の総当たりによる解 法によって求めた最適経路を図 4(b2) に示す. 階層構造を導入しない場合の厳密解である図 $4(\mathrm{a})(L=3.55)$ に比べ ると経路長が若干長くなっている $(L=3.65)$ が, 文字パターン単体の最適化と全体パターンの最適化を完全に分離 して得られた解経路である図 4(b1) $(L=4.39)$ と比較すれば光の効果はあきらかであり, 小規模な問題であることか 


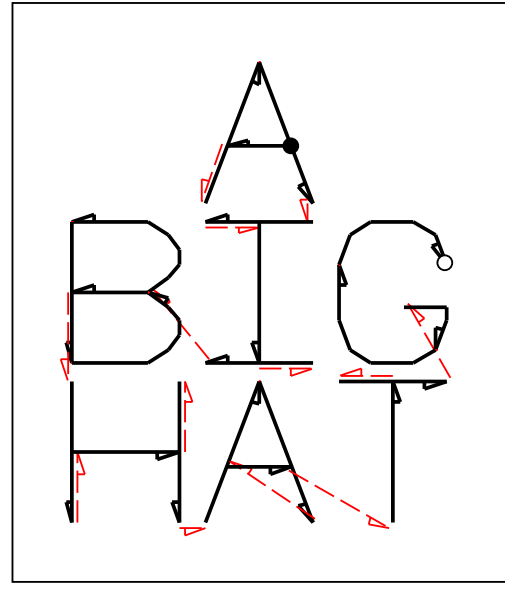

(a) Global optimal solution (CPU time: $784 \mathrm{~s}, L=5.08$ )

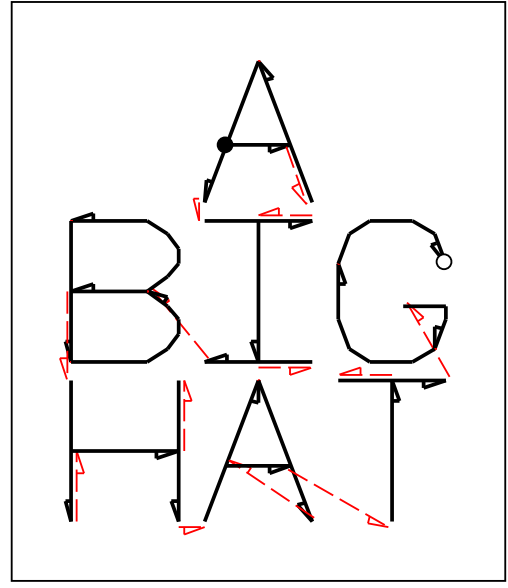

(b) Local optimal solution (CPU time: $0.295 \mathrm{~s}, L=5.08$ )

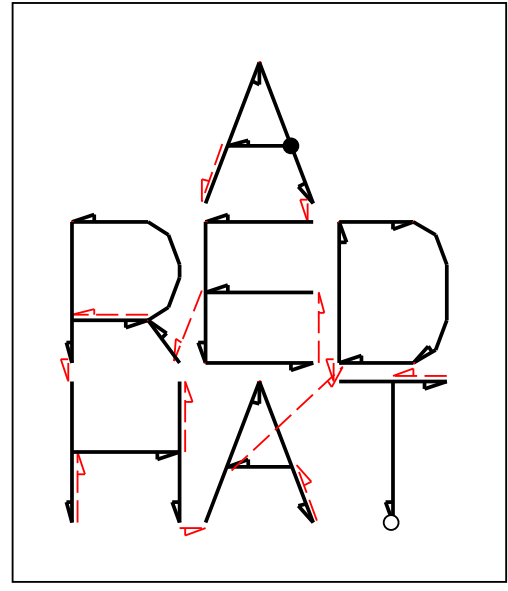

(c) Order depends on character types (CPU time: $0.302 \mathrm{~s}, L=4.98$ )

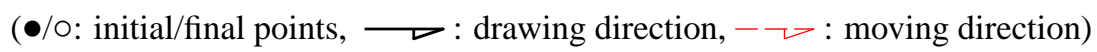

Fig. 6 Global and local optimal solution underhierarchical formulation

ら計算時間も短時間となっている. 例えば, 文字パターン ‘E’ の描画経路では, 図 4(b2) では図 3(b2) の逆順 $(\gamma=4)$ の場合を採用しており, これにより文字パターン間の移動距離を大きく短縮できていることがわかる.

図 5 には同じ文字パターンによって構成される異なる全体パターンの場合の経路探索例を示す. 図 5(a) が厳密 解, (b1) が文字パターン単体の最適化と全体パターンの最適化を完全に分離して得られた解であり, (b2) が文字パ ターンの描画経路の抽象化を適用した結果である. この例でも図 4 の場合と同樣に, 図 5(a) に示す厳密解には及ば ないものの, 文字パターンの描画経路の抽象化を用いた結果 (図 5(b2)) は, 階層構造にもとづく単純な最適化によ る結果 (図 5(b1)) と比較すれば, 兴の経路長が大きく短縮されていることがわかる. また, この場合には図 5(b1) と (b2) では文字パターンの描画順序が異なっており, 個々の文字パターンの経路によって最適な描画順序が影響され ることもわかる.

以上の図 4 および図 5 の結果から, 本研究で提案する, 問題に対する階層構造の導入と下位部分構造の抽象化に よる問題の定式化は, 解の最適性を大きく損なうことなく計算時間の短縮を行う上で有効であることか確認できる.

\section{$6 \cdot 3$ 局所最適化による解の評価}

本研究では, 文字パターンの描画経路の抽象化を用いた問題 (14) に対し, $5 \cdot 2$ 節で述べた総当たりによる解法と 5.3 節で述べた一種の局所最適化による解法を示した. この場合の解法の違いによる計算時間や解の最適性を調べ た計算例を図 6(a), (b) に示す. 両者の結果の差異はわずかで, 冒頭の 'A' の書き出しと光こから 'I' に移る部分のみ である. また, 図 6(c) の場合が兴の一例であるが, 双方の解法において同一の最適経路が得られることも少なくな かった. しかしながら計算時間は大きく短縮されており, 本研究で提案した局所最適化の考え方の有効性が示され ている.

また, 図 6(a), (b) と図 6(c) の結果の比較から, 最適解における文字パターンの描画順序が, 兴の配置のみならず文 字パターンの種類にも依存する場合があることがわかる. 最後の部分の描画順序が, 図 6(a), (b) では 'A' $\rightarrow$ 'T' $\rightarrow$ ' $\mathrm{G}$ ' であり, 直観的にもわかりやすい単純な反時計回りの順序となっているが, 図 6(c) では 'A' $\rightarrow$ 'D' $\rightarrow$ ' $T$ ' すなわち右下 の ‘ $\mathrm{T} ’$ が最後に描画され, 異なる描画順序となっている.

\section{4 文字パターンの描画順序が与えられている場合}

文字パターンの描画順序 $\alpha_{1}, \cdots, \alpha_{N}$ をも設計変数としているこれまで扱った計算例では, これらの置換を扱うた めの $N$ ! 個の組み合わせの評価を行っているため, 扱える文字パターンの数か限定されている. しかしながら, 本論 文で取り扱っているような, 文字によって構成される語句や文章が描画対象となっている場合, 弚の配置が行単位と 


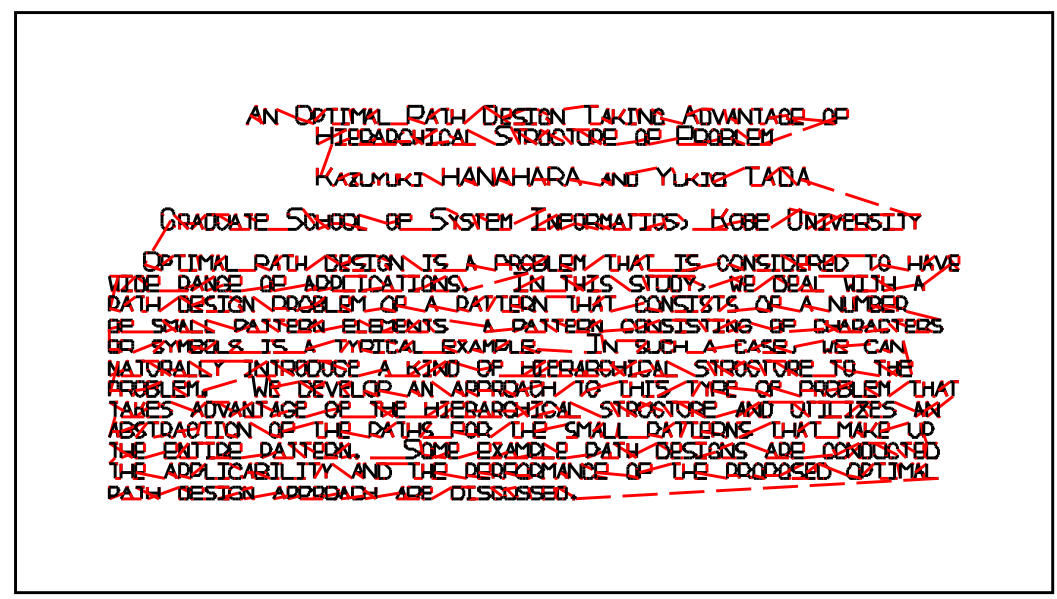

(a) An original default path

$$
(L=46.1)
$$

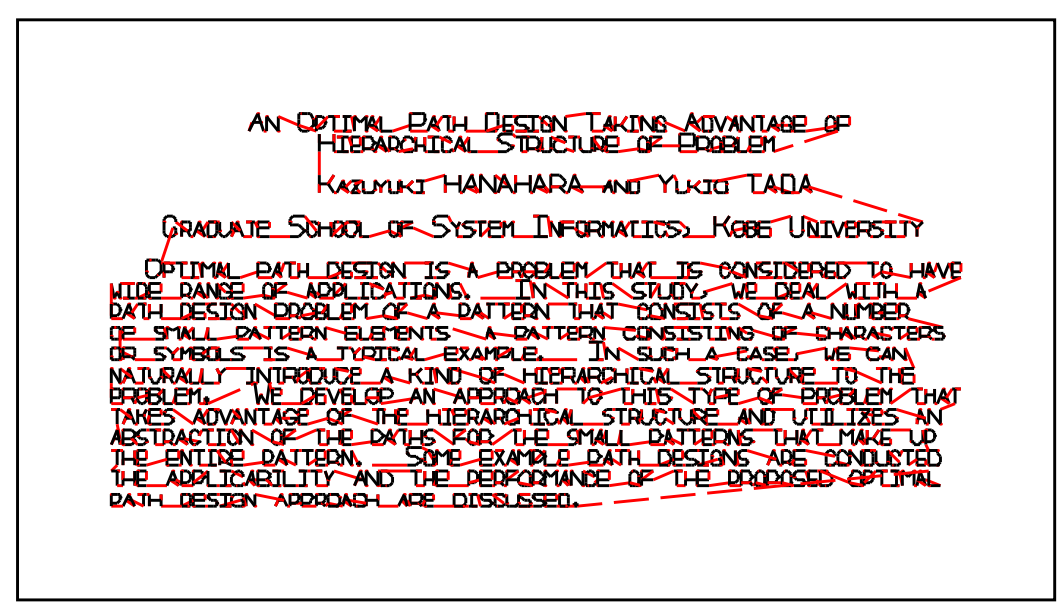

(b) Optimal path design result

(CPU time: $2.95 \mathrm{~s}, L=41.4$ )

$(\bullet / \circ$ : initial/final points, $\longrightarrow$ : drawing direction, $-\neg:$ moving direction)

Fig. 7 Example path design result based only on local optimization

なっているものが多く, 前節の図 6(a), (b) と図 6(c) のような例はあるものの, ある程度の最適性を持つ文字パター ンの描画順序を先験的に与えることができる. このような場合, 文字パターンの描画順序は固定とし, 抽象化した 個々の文字パターンの描画経路, すなわち $\gamma_{1}, \cdots, \gamma_{N}$ のみを設計変数として最適化処理を行うことが考えられ, 前節 で光の有効性が示された局所最適化による解法を適用することができる.

図 7 は, 文字パターンの描画順序を先験的に与えた場合の経路の設計例である. この例における描画順序は, 上の 行から下の行へ, 左から右, 右から左と交互になっており, 直観的にある程度の最適性があると判断できる. 図 7(a) は, 与えられた描画順序に対し, 個々の文字パターン単体での最適な描画経路を単純に適用して得られた, 全体パ ターンの描画経路である. これに対し,同一の描画順序の下で文字パターンの抽象化にもとづく局所最適化処理を 行った結果を図 7(b) に示す. これまでの例よりも格段に規模の大きい問題であるが, この場合には高々 3 秒程度で 最適化処理が完了している. また, 抽象化にもとづく個々の文字パターンの描画経路のみの改善であっても, $10 \%$ 程 度の経路長の短縮が可能であることが示されている. これは,パターンを構成する線と線の間の移動経路を示す赤 の破線が全体として少なくなっていることからも確認できる. 


\section{7. 結言と今後の展開}

本研究では, 経路設計問題に階層構造が存在する場合あるいは階層構造を導入できる場合の最適設計手法につい て検討した. 下位構造のパターン要素 (本研究では文字) の経路を抽象化する問題の定式化を提案し,計算例を通じ てこれによる効率的な最適化が可能であることを示した.

本論文では階層が二つの場合のみを扱つたが, 階層を構成する要素を抽象化して扱う本研究の基本的な考え方は, 多階層の場合にも適用できる. この場合, 問題の基本構造はどの階層においても同じになるため, アルゴリズムとし ては再帰的な取り扱い(13)(14) が可能となる.

抽象化された経路は記録し, 再利用することが可能である. 実際, 本論文で示した計算例においても, $6 \cdot 1$ 節で述べ たように抽象化した結果をデータベース化したものを用いて 6.2 節-6.4 節の計算を行った. 本論文ではこのような 描画経路の抽象化処理を文字の単位に限定したが, 単語や語句, さらには光の組み合わせ等に拡張してゆくことに より, 光れらによって構成されるパターンの効率的な最適設計が期待できる.

6 章で示した計算例では, 抽象化処理における各文字パターンの可能な描画経路の数を $P=6$ とした. この值を大 きくすれば解の最適性の向上が期待できるが, 後の最適設計過程に必要な計算量も増大するため, これらのトレー ドオフを考慮する必要がある. 本論文では, 適用対象がアルファベットであり, 個々の文字を構成する線の数も多く ないため, この值をこれ以上に大きくした場合でも解の最適性の変化はほとんど見られなかった. しかしながら, 適 用対象が漢字やより複雑な図形パターンにより構成される図形の場合の適切な $P$ の值については, 計算量への影響 も含めて検討が必要であると考えている.

前節の計算例に見られるように,階層構造の導入と下位構造の経路の抽象化により実質的な設計変数の数を低減 させた場合においても, 図 7 に示した例のように先験的に何らかの形で適切な描画順序を指定できなければ, 要素 (文字パターン)の描画順序を全て評価することになり,本手法の大規模な問題への適用はできない. これについては 多階層化による各階層における要素数の低減と, 要素描画順序の最適化への近似解法の導入という二つのアプロー チが考えられる.

これらの展開とともに, 明示的な階層構造を持たないより一般的な経路設計問題への階層構造の導入と本研究の 最適化手法の適用等についても今後検討してゆく予定である. 本論文ではいわゆる一筆書きの意味での経路最適設 計を取り扱ったが, 基本的な考え方は階層構造が導入可能な他の問題, 例えば各種のネットワークにおける最短木の 構成 ${ }^{(15)}$ 等にも適用可能であると考えている. また, 階層構造の導入と部分構造の抽象化による最適設計のアプロー チは, 他の分野の問題, 例えば構造最適設計問題等に対しても適用できると考えており, 現在研究を進めている. こ れについても別途機会を得て報告したい.

$$
\text { 文献 }
$$

(1) Bernhard Korte and Jens Vygen, Combinatorial Optimization, Springer-Verlag, (2000, 2002, 2005) (訳: 浅野孝夫, 平田富夫, 小 野孝男, 浅野泰仁, 組合せ最適化 (理論とアルゴリズム), シュプリンガー・フェアラーク東京, (2005)), 21 章.

(2) 文献 ${ }^{(1)}, 21.3$ 節.

(3) B. Golden, L. Bodin, T. Doyle and W. Stewart, Jr., "Approximate Traveling Salesman Algorithms", Operations Research, Vol.28, No.3, Part II, (1980), pp.694-711.

(4) Colin R. Reeves eds., Modern Heuristic Techniques for Combinatorial Problems, John Wiley \& Sons, (1993) (訳: 横山隆一, 奈 良宏一, 佐藤晴夫, 鈴木昭男, 荻本和彦, 陳洛南, モダンヒューリスティックス (組合せ最適化の先端手法), 日刊工業新聞社, (1997)).

（5）内田大輔, 本間経康, 阿部健一, “空間の階層構造を利用したTSP の近似解法について”, 計測自動制御学会東北支部 第 166 回研究集会, (1996), 資料番号 161-3.

(6) Scott M. Graham, Anupam Joshi and Zygmunt Pizlo, "The traveling salesman problem: A hierarchical model", Memory \& Cognition, Vol.28, No.7, (2000), pp.1191-1204.

(7) Yll Haxhimusa, Walter G. Kropatsch, Zygmunt Pizlo, Adrian Ion and Andreas Lehrbaum, "Approximating TSP Solution by MST Based Graph Pyramid", Lecture Notes in Computer Science 4538 (GbRPR 2007, LNCS 4538) (F. Escolano and M. Vento eds.), (2007), pp.295-306. 
(8) 藤田喜久雄, 栗山征典, “配置設計のための階層的最適化計算法の構想”, 第 16 回設計工学・システム部門講演会講演論文 集, (2006), pp.321-324.

(9) Masataka Yoshimura, Masahiko Taniguchi, Kazuhiro Izui and Shinji Nishiwaki, "Hierarchical Arrangement of Characteristics in Product Design Optimization”, Journal of Mechanical Design, Vol.128, (2006), pp.701-709.

(10) Hyung Min Kim, Nestor F. Michelena, Panos Y. Papalambros and Tao Jiang, "Target Cascading in Optimal System Design", Journal of Mechanical Design, Vol.125, (2003), pp.474-480.

(11) David Iclănzan and Dan Dumitrescu, "Overcoming Hierarchical Difficulty by Hill-Climbing the Building Block Structure", Proceedings of the Genetic and Evolutionary Computation Conference (GECCO-2007), (2007), pp.1256-1263.

(12) 田口東, “プロッタの漢字筆順最適化”, 情報処理学会論文誌, Vol.25, No.3, pp.388-393.

(13) Kazuyuki Hanahara and Yukio Tada, “Optimal Structural Design Based on Self-Similarity”, AIAA Journal, Vol.37, No.1, (1999), pp.110-117.

（14）花原和之, 多田幸生, “自己相似構造物の再帰的最適化”, 日本機械学会論文集 A 編, Vol.68, No.649, (2002), pp.828-834.

(15) 笠原一人, 古山正雄, “最短木および階層を有する木の長さに関する考察”, 日本建築学会計画系論文集, No.504, (1998), pp.155-161. 